\title{
Oxysterol-binding protein related-proteins (ORPs) 5 and 8 regulate calcium signaling at specific cell compartments
}

\author{
Pulli, llari
}

2018-06

Pulli , I , Lassila , T , Pan , G , Yan , D , Olkkonen , V M \& Törnquist , K 2018 , '

Oxysterol-binding protein related-proteins (ORPs) 5 and 8 regulate calcium signaling at specific cell compartments ' , Cell Calcium , vol. 72 , pp. 62-69 . https://doi.org/10.1016/j.ceca.2018.03.001

http://hdl.handle.net/10138/303650

https://doi.org/10.1016/j.ceca.2018.03.001

publishedVersion

Downloaded from Helda, University of Helsinki institutional repository.

This is an electronic reprint of the original article.

This reprint may differ from the original in pagination and typographic detail.

Please cite the original version. 


\title{
Oxysterol-binding protein related-proteins (ORPs) 5 and 8 regulate calcium signaling at specific cell compartments
}

\author{
Ilari Pulli ${ }^{\mathrm{a}}$, Taru Lassila ${ }^{\mathrm{a}}$, Guoping Pan ${ }^{\mathrm{b}}$, Daoguang Yan ${ }^{\mathrm{b}}$, Vesa M. Olkkonen ${ }^{\mathrm{c}, \mathrm{d}}$, Kid Törnquist ${ }^{\mathrm{a}, \mathrm{c}, *}$ \\ a Åbo Akademi University, Tykistökatu 6A, 20520 Turku, Finland \\ ${ }^{\mathrm{b}}$ The Key Laboratory of Functional Protein Research of Guangdong Higher Education Institutes, Department of Biotechnology, College of Life Science and Technology, \\ Jinan University, Guangzhou, 510632, China \\ ${ }^{c}$ Minerva Foundation Institute For Medical Research, Biomedicum Helsinki, 00290 Helsinki, Finland \\ ${ }^{\mathrm{d}}$ Department of Anatomy, Faculty of Medicine, FI-00014 University of Helsinki, Finland
}

\section{A R T I C L E I N F O}

\section{Keywords:}

ORP5

ORP8

Caveolae

Mitochondria

Endoplasmic reticulum

Calcium

\begin{abstract}
A B S T R A C T
Oxysterol-binding protein related-protein 5 and 8 (ORP5/8) localize to the membrane contact sites (MCS) of the endoplasmic reticulum (ER) and the mitochondria, as well as to the ER-plasma membrane (PM) MCS. The MCS are emerging as important regulators of cell signaling events, including calcium $\left(\mathrm{Ca}^{2+}\right)$ signaling. ORP5/8 have been shown to interact with phosphatidylinositol-4,5-bisphosphate $\left(\mathrm{PIP}_{2}\right)$ in the $\mathrm{PM}$, and to modulate mitochondrial respiration and morphology. $\mathrm{PIP}_{2}$ is the direct precursor of inositol trisphosphate $\left(\mathrm{IP}_{3}\right)$, a key second messenger responsible for $\mathrm{Ca}^{2+}$-release from the intracellular $\mathrm{Ca}^{2+}$ stores. Further, mitochondrial respiration is linked to $\mathrm{Ca}^{2+}$ transfer from the ER to the mitochondria. Hence, we asked whether ORP5/8 would affect $\mathrm{Ca}^{2+}$ signaling in these cell compartments, and employed genetically engineered aequorin $\mathrm{Ca}^{2+}$ probes to investigate the effect of ORP5/8 in the regulation of mitochondrial and caveolar $\mathrm{Ca}^{2+}$. Our results show that ORP5/8 overexpression leads to increased mitochondrial matrix $\mathrm{Ca}^{2+}$ as well as to increased $\mathrm{Ca}^{2+}$ concentration at the caveolar subdomains of the PM during histamine stimulation, while having no effect on the cytoplasmic $\mathrm{Ca}^{2+}$. Also, we found that ORP5/8 overexpression increases cell proliferation. Our results show that ORP5/8 regulate $\mathrm{Ca}^{2+}$ signaling at specific MCS foci. These local ORP5/8-mediated $\mathrm{Ca}^{2+}$ signaling events are likely to play roles in processes such as mitochondrial respiration and cell proliferation.
\end{abstract}

\section{Introduction}

Members of the oxysterol-binding protein related-protein (OSBPrelated, or ORP) family are involved in the regulation of lipid transport at membrane contact sites (MCS) [1]. MCS are crucial for inter-organellar communication and lipid transfer as well as for the regulation of second messenger molecules, including the calcium ion $\left(\mathrm{Ca}^{2+}\right)$ [2]. ORPs, including ORP5 and ORP8 (ORP5/8), are involved in oncogenesis, possibly through the regulation of membrane lipids and the related downstream signaling events [3]. ORP5/8 have been characterized as countertransporters of phosphatidylinositol-4-phosphate (PI4P) and phosphatidylserine at the interface of the endoplasmic reticulum (ER) and the plasma membrane (PM) [4]. ORP5/8 were also shown to bind to phosphatidylinositol-4,5-bisphosphate $\left(\mathrm{PIP}_{2}\right)$ and modulate its transport from the PM to the ER [5]. Also, it was shown that ORP8 may not bind to $\mathrm{P} 14 \mathrm{P}$ and $\mathrm{PIP}_{2}$ with high affinity [6]. Interestingly, it was recently reported that ORP8 is not strongly associated with the PM in resting conditions but becomes recruited to the PM upon induction of
$\mathrm{PIP}_{2}$ production [7]. Moreover, ORP5/8 were recently found to localize at the ER-mitochondria contact sites where they modulate mitochondrial morphology and function [8]. Approximately $80 \%$ of the ORP5 and ORP8 sequences overlap, they both insert into the ER membrane through a C-terminal transmembrane (TM) domain, contain a lipid transfer domain (ORD) and interact with the PM through a pleckstrin homology (PH) domain [5,9]. The mitochondrial interactions of ORP5/ 8 depend on the ORD domain that binds to the mitochondrial outer membrane protein PTPIP51 [8].

$\mathrm{Ca}^{2+}$ is a ubiquitous second messenger that regulates several cellular functions including proliferation, migration and respiration. Intracellular $\mathrm{Ca}^{2+}$ concentrations are tightly regulated and multiple organelles and cellular compartments are involved in the handling and sensing of $\mathrm{Ca}^{2+}$ signals. $\mathrm{Ca}^{2+}$ is stored in the ER from where it can be released to the cytosol upon different stimuli, such as activation of the inositol trisphosphate receptor $\left(\mathrm{IP}_{3} \mathrm{R}\right)[10] . \mathrm{ER} \mathrm{Ca}^{2+}$ release can be directed towards the mitochondria through the molecular interactions at contact sites designated as mitochondria-associated membranes

\footnotetext{
* Corresponding author

E-mail address: ktornqvi@abo.fi (K. Törnquist).
} 
(MAMs). Mitochondria take up $\mathrm{Ca}^{2+}$ through the mitochondrial calcium uniporter (MCU) to activate the respiratory enzymes, whereas mitochondrial $\mathrm{Ca}^{2+}$ overloading can lead to apoptosis [11,12]. MCU is tightly controlled by accessory proteins, the threshold $\mathrm{Ca}^{2+}$ concentration for MCU activation is high, and hence, ER-mitochondria tethering is essential for the generation of high $\mathrm{Ca}^{2+}$ microdomains that allow for MCU activation [12 17]. Also, local, spatiotemporally restricted $\mathrm{Ca}^{2+}$ signaling events may take place at cytoplasmic leaflets of the PM and at the lipid-rich PM compartments, caveolae, where many molecules related to $\mathrm{Ca}^{2+}$ signaling, such as $\mathrm{PIP}_{2}$, have been shown to localize [18,19]. Importantly, MAMs and caveolae-ER contacts are implicated in oncogenesis, and $\mathrm{Ca}^{2+}$ transfer trough the $\mathrm{IP}_{3} \mathrm{R}$ to the mitochondria is essential for cancer cell metabolism [20,21]. Further, ORP5/8 reside at the MAMs, which have been recognized to play a role in cardiovascular pathophysiology in part through disturbed mitochondrial $\mathrm{Ca}^{2+}$ signaling [22]. Also, the possible involvement of ORP5/8 in $\mathrm{Ca}^{2+}$ signaling has been recently reviewed [23].

Considering that ORP5/8 are involved in the physical interactions and lipid transfer between the ER, the PM and the mitochondria, we hypothesized that this might also affect the $\mathrm{Ca}^{2+}$ handling at these membrane interfaces. Further, ORP5/8 modulate the PM levels of $\mathrm{PIP}_{2}$ [5], which is the substrate for phospholipase C (PLC) that hydrolyzes $\mathrm{PIP}_{2}$ to $\mathrm{IP}_{3}$ and diacylglycerol (DAG). IP 3 binds to and activates the $\mathrm{IP}_{3} \mathrm{R}$ in the ER, and DAG activates many of the PM Ca ${ }^{2+}$ channels. The ORP5/8 mediated modulation of $\mathrm{PIP}_{2}$ transport might thus affect intracellular $\mathrm{Ca}^{2+}$ signaling. Therefore, we set out to characterize the importance of ORP5/8 in regulating $\mathrm{Ca}^{2+}$ specifically in the mitochondria, at the caveolar compartments of the PM, and in the overall cytoplasm.

\section{Methods}

\subsection{Cell culture and plasmid and siRNA transfections}

HeLa cells were used in all experiments of this study. The cells were routinely cultured in DMEM (\#D6046, Sigma-Aldrich) medium supplemented with $10 \%$ fetal bovine serum and $1 \%$ penicillin/streptomycin (Life Technologies). The cells were grown in a humidified incubator at $37^{\circ} \mathrm{C}$ and $5 \% \mathrm{CO}_{2}$. The GFP-ORP5 expression plasmid is described in [8]. The human ORP8 ORF was inserted in the XbaI site of pEGFP-C1 (Clontech/TakaraBio, Mountain View, CA). ORP5 and 8 specific Silencer Select siRNAs (s377 and s41692, respectively) and a non-targeting control siRNA (Cat n:o 4390846) were purchased from ThermoFisher Scientific (Waltham, MA). HeLa cells were transfected for $24 \mathrm{~h}$ with the GFP-ORP5 or 8 plasmids, or plain pEGFP-C1 as a negative control. TurboFect (\#R0531, Thermo Scientific) transfection reagent and OptiMEM media (\#31985-070, Life Technologies) were used for all plasmid transfections. siRNA transfections were carried out using HiPerfect transfection reagent (Qiaqen).

\subsection{Intracellular calcium measurements by employing aequorin}

The luminescent $\mathrm{Ca}^{2+}$ binding recombinant protein, aequorin, was employed to measure $\mathrm{Ca}^{2+}$ concentrations in the cytoplasm, in the mitochondria, and at the caveolae as previously described in [24,25]. Briefly, 5000 10,000 HeLa cells were seeded on to a 96-well cell culture plate for measurements when a plate reader setup was employed (HIDEX Sense plate reader, HIDEX corp., Turku, Finland). Alternatively, when employing an in-house built single-tube luminometer setup with a perfusion chamber, 75000 100,000 HeLa cells were seeded on to 13$\mathrm{mm}$ poly-L-lysine coated coverslips in a 12-well plate. The cells were grown overnight and transfected with the desired aequorin plasmids. The measurements were conducted on the following day. Before every measurement, the cells were incubated with $5 \mathrm{M}$ coelenterazine (SynChem) for one hour in HEPES-buffered saline solution (HBSS: $118 \mathrm{mM} \mathrm{NaCl}, 4.6 \mathrm{mM} \mathrm{KCl}, 10 \mathrm{mM}$ glucose, $20 \mathrm{mM}$ HEPES with $1 \mathrm{mM}$
$\mathrm{CaCl} 2$ or, alternatively, $150 \mathrm{M}$ EGTA, when $\mathrm{Ca}^{2+}$ free buffer was used). The cells were stimulated with $100 \mathrm{M}$ histamine in $\mathrm{Ca}^{2+}$ containing or in $\mathrm{Ca}^{2+}$ free HBSS depending on the experimental setup. The cells were primed for store-operated calcium entry (SOCE) by treating the cells with $1 \mathrm{M}$ thapsigargin (TG) for five minutes in the presence of 150 M EGTA whereafter the SOCE was induced by perfusing the cells with HBSS buffer containing $1 \mathrm{M} \mathrm{TG}$ and $1 \mathrm{mM} \mathrm{Ca}^{2+}$. At the end of each experiment, the cells were lysed with $100 \mathrm{M}$ digitonin in the presence of $10 \mathrm{mM} \mathrm{Ca}^{2+}$ to obtain the maximal light production values of the sample. The obtained luminescence raw data values were analysed and transformed as described in [24]. The cytoplasmic and mitochondria targeting aequorin constructs were a kind gift from professor Paolo Pinton (University of Ferrara, Italy).

\subsection{Calcium measurements by employing fura-2 AM}

For Fura-2 AM measurements 5000 10,000 cells were seeded on to 96-well plates. The cells were grown overnight and transfected with the desired constructs. On the following day, they were washed twice with HBSS and incubated with Fura-2 AM (2 M, Life Technologies) for $30 \mathrm{~min}$ at room temperature. Then, the cells were washed twice and incubated for $15 \mathrm{~min}$ in HBSS at room temperature, washed twice and transferred to the HIDEX plate reader. The excitation filters were set to 340 and 380 nanometers, respectively, and the emission was read at 510 nanometers. The fluorescence signal was recorded at one second intervals and the ratios of the two excitation wavelengths were calculated for each time point. These values were used for analysis of the data.

\subsection{Western blot analysis}

Cell lysates were prepared by washing the cells three times with PBS, whereafter Laemmli sample buffer was added to the samples. The lysates were boiled for $5 \mathrm{~min}$ and separated by SDS-PAGE, whereafter the proteins were transferred to a nitrocellulose membrane. The membranes were subjected to the desired primary or secondary antibodies in a phosphate buffered saline (PBS) solution containing 1\% bovine serum albumin. The ORP5 antibodies were from Sigma-Aldrich and the ORP8 antibodies are described in [26]. HSC70 antibody was purchased from Enzo life sciences. The dilutions for the primary antibodies were 1:1000 and 1:3000 for the secondary antibodies (antirabbit HRP-conjugated antibody, BioRad; anti-rat HRP-conjugated antibody, Cell Signaling Technology). The protein bands were visualized by chemiluminescence (ECL, Perkin Elmer). Anti-Xpress and AntiXpress-HRP antibodies (Invitrogen) were employed for the detection of epitope-tagged ORP5/8 constructs that were used in the $\mathrm{IP}_{3}$ production measurements.

\subsection{Measurement of $I P_{3}$ production}

$\mathrm{IP}_{3}$ was measured using the HitHunter $\mathrm{IP}_{3}$ Fluorescence Polarization Assay Kits (DiscoverRx Tech, Fremont, CA, USA). Briefly, 10,000 cells transfected with pcDNA4 HisMax C, ORP5 or ORP8 vector in 96-well plates (Corning, USA) were treated with $10 \mathrm{M}$ histamine for the designated times, and the cellular reaction was terminated by adding $0.2 \mathrm{~N}$ perchloric acid. The plate was shaken at 650 r.p.m. for $5 \mathrm{~min}$. Then 20 ul mixture buffer from 96-well plates were tansferred into black 384-well plates (Greiner, Germany). The $\mathrm{IP}_{3}$ tracer was subsequently added to each well, and the $\mathrm{IP}_{3}$ 
overnight. Thereafter the cells were transfected with plasmid constructs carrying GFP, GFP-ORP5 or GFP-ORP8, respectively. The cells were grown for $48 \mathrm{~h}$ and subjected to ${ }^{3} \mathrm{H}$-thymidine $(0.4 \mathrm{Ci} / \mathrm{ml})$ for the final four hours. Thereafter the cells were washed three times in ice-cold PBS on ice, followed by a 10-min incubation in 5\% trichloric acetic acid, and then incubated for $10 \mathrm{~min}$ with $0.1 \mathrm{M} \mathrm{NaOH}$. Then the suspension was mixed 1:5 with Optiphase Hisafe 3 scintillation liquid (PerkinElmer). Radioactivity was measured using a Wallac 1410 liquid scintillation counter. ${ }^{3} \mathrm{H}$-thymidine was from PerkinElmer.

\subsection{Confocal microscopy}

The cells were plated on poly-L-lysine coated coverslips, grown overnight and transfected with plasmid constructs carrying GFP, GFPORP5 or GFP-ORP8, respectively. The cells were then grown overnight, washed in PBS, fixed using 4\% paraformaldehyde and mounted with Mowiol mounting medium. Microscopy was conducted by employing a Leica SP5 (Wetzlar, Germany) confocal microscope.

\subsection{Statistics}

The results are shown as the mean \pm S.E.M. Statistical analysis of the data was conducted by unpaired Student $s t$-test when two means were compared or by One-Way Anova with Tukey s post-hoc test when three or more means were compared. The GraphPad Prism 5 program (GraphPad Software Inc., San Diego, CA) was used for the statistical analyses. A P-value below 0.05 was considered statistically significant.

\section{Results}

To assess the importance of ORP5/8 in regulating $\mathrm{Ca}^{2+}$ in intracellular compartments, we employed the luminescent calcium indicator protein, aequorin. Upon transient expression, wild-type aequorin localizes to the cytosol, but aequorin has been genetically engineered to target different cell compartments such as the mitochondria and the caveolae $[24,25]$. First, we set out to measure cytoplasmic and mitochondrial $\mathrm{Ca}^{2+}$ upon overexpression of GFP-ORP5 or ORP8 in the presence of extracellular $\mathrm{Ca}^{2+}$. To induce the intracellular $\mathrm{Ca}^{2+}$ fluxes we used the G-protein coupled receptor (GPCR) agonist, histamine. Our results show that the cytoplasmic $\mathrm{Ca}^{2+}$ was not affected in cells overexpressing either ORP5 or ORP8 when stimulated with 100 M histamine, whereas ORP5 overexpression resulted in increased mitochondrial $\mathrm{Ca}^{2+}$ uptake upon histamine stimulation (Fig. 1A). To further explore the possible involvement of ORP8 in the ER-mitochondria $\mathrm{Ca}^{2+}$ flux, we excluded the extracellular $\mathrm{Ca}^{2+}$ from the experimental setting. In this condition, ORP8 overexpression significantly increased mitochondrial $\mathrm{Ca}^{2+}$ uptake upon stimulation with histamine (Fig. 1B). Treating the cells with 10 M BAPTA-AM for $1 \mathrm{~h}$ completely abolished the mitochondrial $\mathrm{Ca}^{2+}$ responses (Supplementary Fig. 1A). Overexpression of the GFP-ORP5/8 constructs was confirmed by microscopy (Fig. 1C). However, knock-down of ORP5 and

8 separately or simultaneously did not affect the stimulation-evoked mitochondrial $\mathrm{Ca}^{2+}$ uptake (Fig. 2A). Efficient knock-down of ORP5/8 was confirmed by western blotting (Fig. 2B)

As mentioned above, ORP5 and 8 bind to $\mathrm{PIP}_{2}$ and are localized to the ER-PM contact sites, and caveolae are enriched in PIP $_{2}[5,19]$. Therefore, we tested whether the caveolar microdomain of $\mathrm{Ca}^{2+}$ might be affected by ORP5/8 overexpression or silencing. We found that ORP8 overexpression slightly but significantly increased the histamineinduced $\mathrm{Ca}^{2+}$ concentration at the caveolae $\left(\left[\mathrm{Ca}^{2+}\right]_{\text {cav }}\right)$ in the presence of extracellular $\mathrm{Ca}^{2+}$ (Fig. 3A) This effect was more pronounced in the absence of extracellular $\mathrm{Ca}^{2+}$ (Fig. 3B). Also ORP5 overexpression significantly augmented the histamine-induced $\left[\mathrm{Ca}^{2+}\right]_{\text {cav }}$ (Fig. 3C). In contrast, knockdown of ORP5/8 did not affect $\left[\mathrm{Ca}^{2+}\right]_{\text {cav }}$ (Fig. 3D).

Caveolae may harbour molecules that are involved in the regulation of the store-operated $\mathrm{Ca}^{2+}$ entry (SOCE) [18]. Hence, we investigated whether ORP5/8 would affect $\left[\mathrm{Ca}^{2+}\right]_{\text {cav }}$ during thapsigargin (TG)-induced SOCE. We found that overexpression of ORP5 or 8 was without an effect on SOCE at the caveolar microdomain (Fig. 4A\&B). Interestingly, cytoplasmic $\mathrm{Ca}^{2+}$ was slightly but significantly inhibited by ORP5 overexpression during TG-induced SOCE (Fig. 4C). Further, ORP5 overexpression inhibited the cytosolic $\mathrm{Ca}^{2+}$ flux in an experimental setting where $\mathrm{Ca}^{2+}$ was present in the extracellular milieu during the TG treatment (Supplementary Fig. 1B).

Even though we could not detect an effect of ORP5 or 8 on the agonist-induced cytoplasmic $\mathrm{Ca}^{2+}$, we found it interesting to test whether the overexpression of these proteins might modify the release of $\mathrm{IP}_{3}$ by PLCs. Therefore, the cellular $\mathrm{IP}_{3}$ concentration was measured upon histamine stimulation. We found that ORP5 overexpression significantly augments $\mathrm{IP}_{3}$ production whereas ORP8 overexpression was without an effect (Fig. 5).

ORP proteins have been implicated in the control of cell proliferation. It has been shown that ORP4 silencing halts cell proliferation and that ORP4L modulates proliferation through $\mathrm{Ca}^{2+}$ and the nuclear factor of activated T cells (NFAT) pathway $[27,28]$. Also, it is well established that intracellular $\mathrm{Ca}^{2+}$ plays key roles in controlling cell proliferation [10]. Hence, we used the ${ }^{3} \mathrm{H}$-thymidine incorporation assay to quantify the proliferation of GFP, GFP-ORP5 or GFP-ORP8 transfected HeLa cells. Interestingly, we found that the ORP5/8 overexpressing cells showed a significant increase in proliferation as compared to the GFP-transfected controls (Fig. 6).

\section{Discussion}

In this study we present evidence that elevated cellular levels of the OSBP-related proteins ORP5 or 8 modify $\mathrm{Ca}^{2+}$ homeostasis in an organelle-specific fashion. Experiments with caveolae- or mitochondriatargeted aequorin $\mathrm{Ca}^{2+}$ probes demonstrated that while neither ORP5 nor 8 overexpression had a significant effect on the cytoplasmic $\mathrm{Ca}^{2+}$ concentration in histamine-stimulated cells, ORP5 and 

A
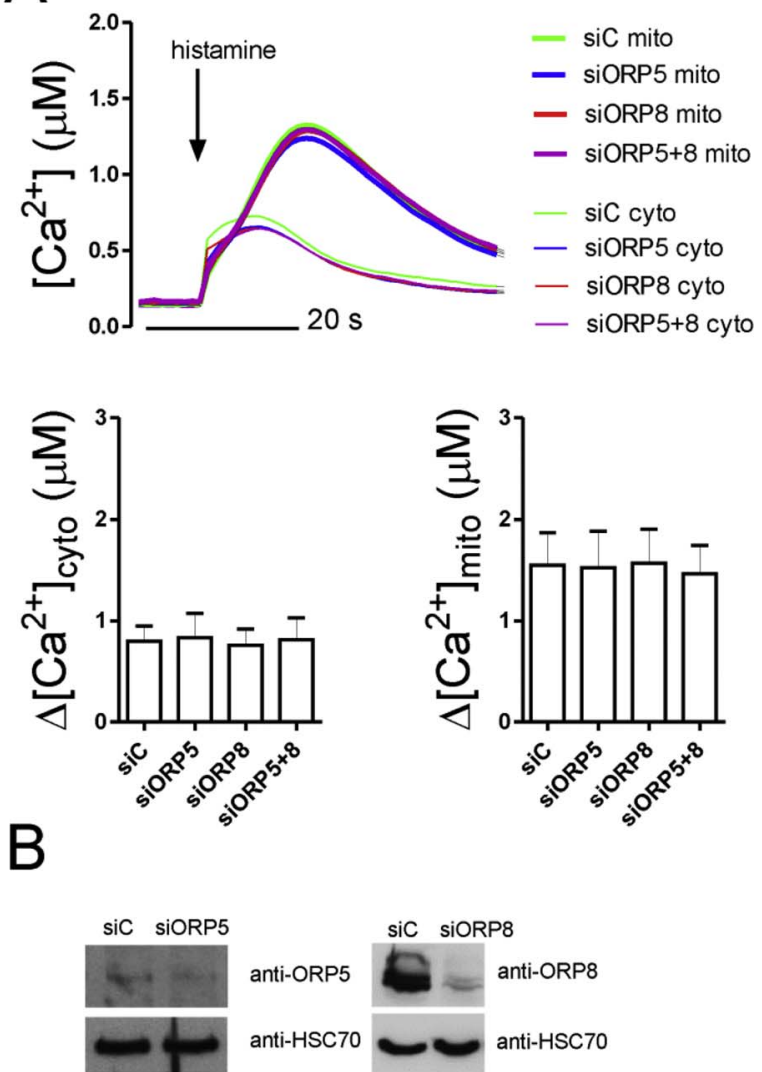

Fig. 2. Downregulation of ORP5/8 does not affect mitochondrial calcium upon $100 \mathrm{M}$ histamine treatment. A) HeLa cells transfected with control siRNA or siRNAs targeting ORP5, ORP8 or ORP5 and 8 were stimulated with $100 \mathrm{M}$ histamine in the presence of $1 \mathrm{mM} \mathrm{Ca}^{2+}$. The bars represent the mean \pm SEM of the change in the calcium concentration during the experiment (maximal value basal value). $\mathrm{N}=3$. B) Representative western blot images showing the effect of ORP5 (left panel) and ORP8 (right panel) targeting siRNAs as compared to the control siRNAs (siC).

calcium was only detectable in the absence of extracellular $\mathrm{Ca}^{2+}$. This may be explained by the previous finding that ORP8 is more evenly distributed throughout the ER membranes whereas ORP5 is more specifically localized to the MAM MCS [4,8]. Thus, the effect of ORP8 overexpression on mitochondrial $\mathrm{Ca}^{2+}$ uptake was unmasked when the extracellular $\mathrm{Ca}^{2+}$ was chelated and the $\mathrm{IP}_{3}$-releaseable $\mathrm{ER} \mathrm{Ca}{ }^{2+}$ was the primary source of $\mathrm{Ca}^{2+}$. The data suggests that ORP5/8, and ORP5 in particular, has the ability to organize and expand an ER-mitochondrial membrane contact domain at which $\mathrm{Ca}^{2+}$ transport is active. The physical association of ORP5/8 with PTPIP51 is consistent with this notion, considering that the mitochondrial outer membrane protein PTPIP51 in a complex with the ER protein VAPB is also reported to control the ER-mitochondria associations [8,32]. Further, ORP5/8 are involved in the modulation of mitochondrial morphology and the integrity of the mitochondrial network, key aspects which are known to affect the regulation of mitochondrial $\mathrm{Ca}^{2+}[8,33]$.

It has been reported that ER and PM can form junctions at the caveolae [34]. Also, the interaction of $\mathrm{IP}_{3} \mathrm{R} 1$ and 3 with the $\mathrm{Ca}^{2+}$. conducting transient receptor potential canonical cation channels 1 and 3 (TRPC1, 3), respectively, is coordinated at the caveolae [35,36]. Further, caveolae are considered as important signaling hubs that control a wide range of cellular events such as migration, adhesion and invasion, and these processes are modulated by $\mathrm{Ca}^{2+}$ signals $[18,34]$. Our results showing that ORP5/8 modulate $\mathrm{Ca}^{2+}$ at the caveolae may thus in part offer new mechanistic insight to the previously reported ORP5/8-mediated regulation of invasion and migration [3,37].

We did not observe disturbances in mitochondrial or caveolar
A
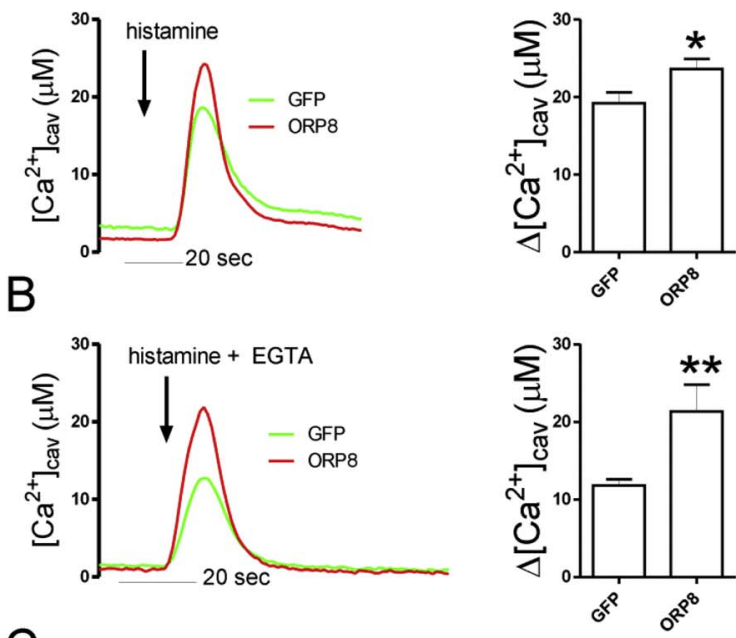

C
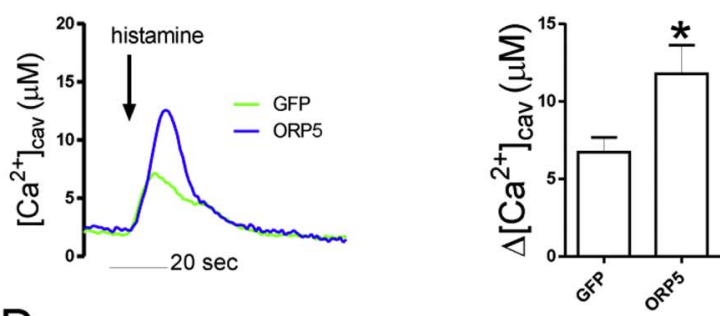

D
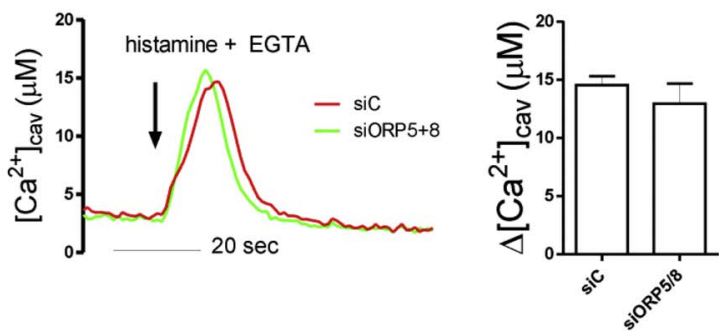

Fig. 3. Histamine-induced $\mathrm{Ca}^{2+}$ flux at the caveolar micro-domain is augmented by ORP5/8 overexpression whereas knock-down of ORP5/8 was without an effect. A) ORP8 overexpression increases $\left[\mathrm{Ca}^{2+}\right]_{\mathrm{cav}}$ during $100 \mathrm{M}$ histamine-stimulation in the presence of $1 \mathrm{mM} \mathrm{Ca}^{2+}$. B) The effect of ORP8 overexpression on $\left[\mathrm{Ca}^{2+}\right]_{\mathrm{cav}}$ is more pronounced in the presence of 150 M EGTA. C) ORP5 overexpression augments $\left[\mathrm{Ca}^{2+}\right]_{\text {cav }}$ during histamine-stimulation in the presence of $1 \mathrm{mM} \mathrm{Ca}^{2+}$. D) Simultaneous knock-down of ORP5 and 8 is without an effect on $\left[\mathrm{Ca}^{2+}\right]_{\text {cav }}$ during histamine-stimulation in the presence of 150 M EGTA. The traces are representative and the bars represent the mean \pm SEM of the change in the calcium concentration during the experiment (maximal value basal value). *, $\mathrm{p}<0.05 ;{ }^{* *}, \mathrm{p}<0.01 . \mathrm{N}=3-8$.

calcium upon siRNA-mediated knock-down of ORP5, 8 or both. This is consistent with the previous observation that inter-organelle MCSs rarely depend on a single tethering component. For example, in yeast the abolishment of the ER-PM contact sites required the genetic disruption of six MCS components [38]. We also find it possible that knocking down the ORPs involved in the vital MCS calcium transport processes will lead to compensatory responses in order to maintain organelle $\mathrm{Ca}^{2+}$ homeostasis, which may lead to a dampening of the effect of ORP5/8 knock-down on mitochondrial or caveolar $\mathrm{Ca}^{2+}$. Also, the partial knock-down of ORP5/8 proteins achieved by siRNA treatment may not be sufficient to induce significant effects in the robust $\mathrm{Ca}^{2+}$ fluxes that were studied. Further, we found that ORP5/8 overexpression did not affect SOCE at the caveolar microdomain of the plasma membrane. However, cytoplasmic $\mathrm{Ca}^{2+}$ was slightly reduced in ORP5 overexpressing cells during TG-induced SOCE. Interestingly,SOCE proteins STIM1 and Orai1 are translocated from the PIP $_{2}{ }^{-}$ 
A
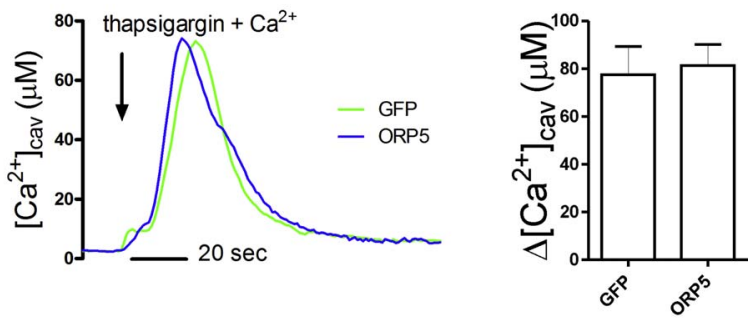

$\mathrm{B}$

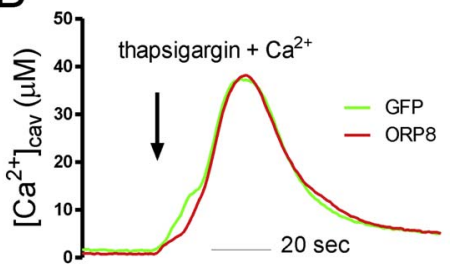

C

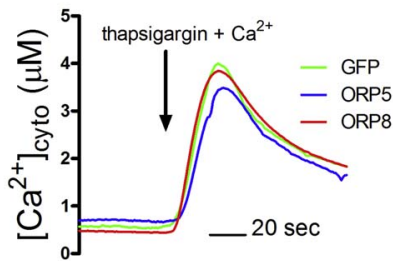

A

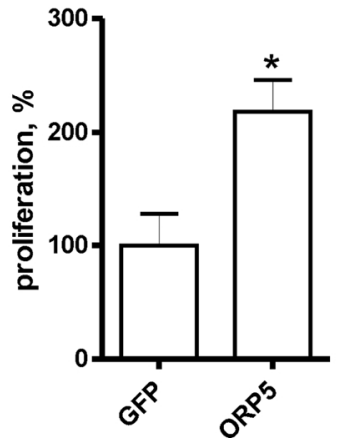

B

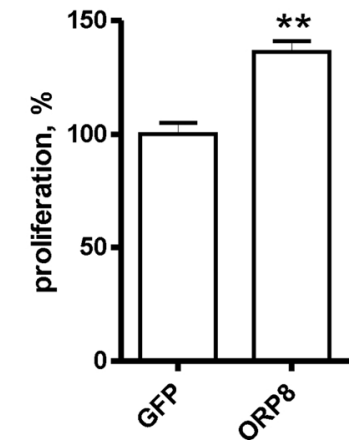

Fig. 6. Overexpression of ORP5 (A) or ORP8 (B) increases cell proliferation. The proliferation of Hela cells transfected for $48 \mathrm{~h}$ with plain GFP (control) or the GFP-ORP constructs was determined by ${ }^{3} \mathrm{H}$-thymidine incorporation during $4 \mathrm{~h}$. The bars represent the mean \pm SEM of 34 experiments. ${ }^{*} \mathrm{p}<0.05$, ${ }^{* *} \mathrm{p}<0.01$.

differences in the activation of the histamine-induced $\mathrm{Ca}^{2+}$ fluxes and SOCE, SOCE being activated through STIM and ORAI oligomerization in response to the $\mathrm{IP}_{3}$-mediated ER emptying [40,41].

We also found that ORP5/8 overexpression increases the proliferation of HeLa cells. This is in line with the similar findings regarding ORP4L [28]. Further, ORP5 overexpression is associated with tumor cell invasion [3] and proliferation (unpublished observations disclosed in ref. [3] and published during the revision of the present article [42]). In contrast to our finding, ORP8 has been linked to inhibition of cell growth in gastric cancer cells through induction of ER stress and to initiation of apoptosis in hepatocellular cancer cells through the Faspathway [43,44]. Interestingly, $\mathrm{Ca}^{2+}$ is essential for the initiation of Fas-mediated apoptosis [45], and ER stress, as well as the regulation of apoptotic events are associated with ER-mitochondria $\mathrm{Ca}^{2+}$ transfer [46]. On the other hand, $\mathrm{Ca}^{2+}$ handling at the ER-mitochondria interfaces is involved in the regulation of energy metabolism and cell proliferation [47]. Therefore, we find it possible that ORP8-mediated changes in mitochondrial $\mathrm{Ca}^{2+}$ homeostasis may modulate cell fate in a context-dependent manner.

In conclusion, our results provide evidence for the importance of ORP5/8 in regulating $\mathrm{Ca}^{2+}$ in the mitochondrial matrix as well as at the caveolar sub-compartments of the PM. These findings corroborate the role of ORP5/8 as MCS proteins facilitating organelle interactions at specific membrane interfaces. ORP5 overexpression. These results are not contradictory as histamineinduced $\mathrm{Ca}^{2+}$ fluxes and SOCE recruit different proteins and signaling pathways, even if these pathways are interconnected (e.g. SOCE following the $\mathrm{IP}_{3}$-mediated $\mathrm{Ca}^{2+}$ release). Hence, there are kinetic

A

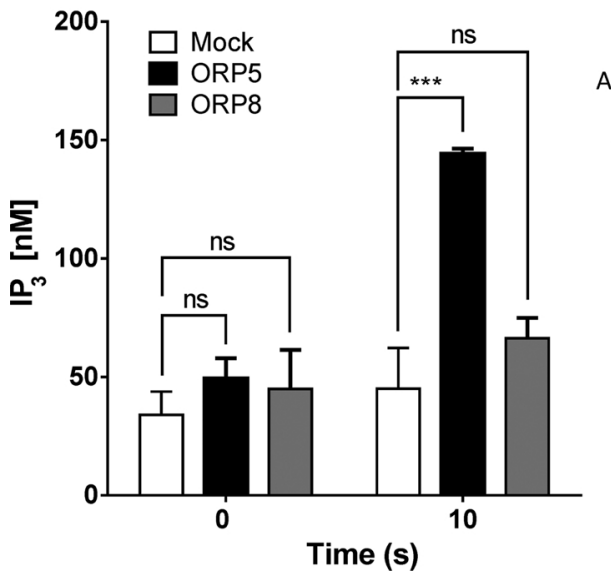

Fig. 5. Overexpression of ORP5 increases cellular $\mathrm{IP}_{3}$ levels during histamine stimulation whereas ORP8 overexpression is without an effect. The $\mathrm{IP}_{3}$ concentration was measured from unstimulated cells (time point 0 ), and at $10 \mathrm{~s}$ after histamine stimulation (A). The expression of epitopetagged recombinant ORP5 and ORP8 was confirmed by western blot using anti-Xpress epitope antibodies (B). ${ }^{* * *} \mathrm{P}<0.001, \mathrm{~N}=3$. 


\section{Conflict of interest}

The authors declare that there are no conflicts of interest.

\section{Acknowledgements}

This work was supported by grants to I.P. from the Magnus Ehrnrooths stiftelse, Finsk-Norska medicinska stiftelsen, Tor, Joe och Pentti Borgs Minnesfond, Oscar Öflunds stiftelse, Waldemar Von Frenckells stiftelse, K. Albin Johanssons stiftelse, Ida Montins stiftelse and Svenska Kulturfonden. V.M.O. was supported by the Academy of Finland (grant 285223), the Sigrid Juselius Foundation, the Finnish Foundation for Cardiovascular Research and the Magnus Ehrnrooths stiftelse. K.T. was supported by the Sigrid Juselius Foundation and the Liv och Hälsa Foundation.

\section{Appendix A. Supplementary data}

Supplementary data associated with this article can be found, in the online version, at https://doi.org/10.1016/j.ceca.2018.03.001.

\section{References}

[1] H. Kentala, M. Weber-Boyvat, V.M. Olkkonen, OSBP-related protein family: mediators of lipid transport and signaling at membrane contact sites, Int. Rev. Cell Mol Biol. 321 (2016) 299 340, http://dx.doi.org/10.1016/bs.ircmb.2015.09.006.

[2] S. Muallem, W.Y. Chung, A. Jha, M. Ahuja, Lipids at membrane contact sites: cell signaling and ion transport, EMBO Rep. 18 (2017) e201744331, http://dx.doi.org/ 10.15252/embr.201744331.

[3] X. Du, N. Turner, H. Yang, The role of oxysterol-binding protein and its related proteins in cancer, Semin. Cell Dev. Biol. S1084 S9521 (17) (2017) 3001230015.

[4] J. Chung, F. Torta, K. Masai, L. Lucast, H. Czapla, L.B. Tanner, P. Narayanaswamy, M.R. Wenk, F. Nakatsu, P. De Camilli, INTRACELLULAR TRANSPORT. PI4P/ phosphatidylserine countertransport at ORP5- and ORP8-mediated ER-plasma membrane contacts, Science 349 (2015) 428 432, http://dx.doi.org/10.1126/ science.aab1370.

[5] R. Ghai, X. Du, H. Wang, J. Dong, C. Ferguson, A.J. Brown, R.G. Parton, J.W. Wu, H. Yang, ORP5 and ORP8 bind phosphatidylinositol-4, 5-biphosphate (PtdIns $(4,5) \mathrm{P}$ 2) and regulate its level at the plasma membrane, Nat. Commun. 8 (2017) 5, http:// dx.doi.org/10.1038/s41467-017-00861-5.

[6] M. Lee, G.D. Fairn, Both the $\mathrm{pH}$ domain and N-terminal region of oxysterol-binding protein related protein $8 \mathrm{~S}$ are required for localization to PM-ER contact sites, Biochem. Biophys. Res. Commun. 496 (2018) 1088 1094, http://dx.doi.org/10. 1016/j.bbrc.2018.01.138.

[7] M. Sohn, M. Korzeniowski, J.P. Zewe, R.C. Wills, G.R.V. Hammond, J. Humpolickova, L. Vrzal, D. Chalupska, V. Veverka, G.D. Fairn, E. Boura, T. Balla, PI $(4,5) P 2$ controls plasma membrane PI4P and PS levels via ORP5/8 recruitment to ER-PM contact sites, J. Cell Biol. (2018), http://dx.doi.org/10.1083/jcb.201710095 (jcb.201710095).

[8] R. Galmes, A. Houcine, A.R. van Vliet, P. Agostinis, C.L. Jackson, F. Giordano, ORP5/ORP8 localize to endoplasmic reticulum-mitochondria contacts and are involved in mitochondrial function, EMBO Rep. 17 (2016) 800 810, http://dx.doi. org/10.15252/embr.201541108.

[9] V.M. Olkkonen, S. Li, Oxysterol-binding proteins: sterol and phosphoinositide sensors coordinating transport, signaling and metabolism, Prog. Lipid Res. 52 (2013) 529 538, http://dx.doi.org/10.1016/j.plipres.2013.06.004.

[10] M.J. Berridge, P. Lipp, M.D. Bootman, The versatility and universality of calcium signalling, Nat. Rev. Mol. Cell Biol. 1 (2000) 11 21, http://dx.doi.org/10.1038/ 35036035 .

[11] S. Marchi, M. Bittremieux, S. Missiroli, C. Morganti, S. Patergnani, L. Sbano, A. Rimessi, M. Kerkhofs, J.B. Parys, G. Bultynck, C. Giorgi, P. Pinton, Endoplasmic reticulum-mitochondria communication through $\mathrm{Ca} 2+$ signaling: the importance of mitochondria-associated membranes (MAMs), Adv. Exp. Med. Biol. 997 (2017) 49 67, http://dx.doi.org/10.1007/978-981-10-4567-7 4.

[12] D. De Stefani, M. Patron, R. Rizzuto, Structure and function of the mitochondrial calcium uniporter complex, Biochim. Biophys. Acta Mol. Cell Res. 2015 (1853) 2006 2011, http://dx.doi.org/10.1016/j.bbamcr.2015.04.008.

[13] G. Csordás, P. Várnai, T. Golenár, S. Roy, G. Purkins, T.G. Schneider, T. Balla, G. Hajnóczky, Imaging interorganelle contacts and local calcium dynamics at the ER-mitochondrial interface, Mol. Cell. 39 (2010) 121 132, http://dx.doi.org/10. 1016/j.molcel.2010.06.029.

[14] M. Giacomello, I. Drago, M. Bortolozzi, M. Scorzeto, A. Gianelle, P. Pizzo, T. Pozzan, $\mathrm{Ca} 2+$ hot spots on the mitochondrial surface are generated by $\mathrm{Ca} 2+$ mobilization from stores, but not by activation of store-operated $\mathrm{Ca} 2+$ channels, Mol. Cell. 38 (2010) 280 290, http://dx.doi.org/10.1016/J.MOLCEL.2010.04.003.

[15] K. Mallilankaraman, P. Doonan, C. Cárdenas, H.C. Chandramoorthy, M. Müller, R. Miller, N.E. Hoffman, R.K. Gandhirajan, J. Molgó, M.J. Birnbaum, B.S. Rothberg, D.-O.D. Mak, J.K. Foskett, M. Madesh, MICU1 is an essential gatekeeper for MCUmediated mitochondrial $\mathrm{Ca}(2+)$ uptake that regulates cell survival, Cell 151 (2012)
630 644, http://dx.doi.org/10.1016/j.cell.2012.10.011.

[16] H. Vais, K. Mallilankaraman, D.-O.D. Mak, H. Hoff, R. Payne, J.E. Tanis, J.K. Foskett, EMRE is a matrix ca(2+) sensor that governs gatekeeping of the mitochondrial $\mathrm{Ca}(2+)$ uniporter, Cell Rep. 14 (2016) 403 410, http://dx.doi.org/10. 1016/j.celrep.2015.12.054.

[17] M. Patron, V. Checchetto, A. Raffaello, E. Teardo, D. Vecellio Reane, M. Mantoan, V. Granatiero, I. Szabò, D. De Stefani, R. Rizzuto, MICU1 and MICU2 finely tune the mitochondrial Ca2 + uniporter by exerting opposite effects on MCU activity, Mol. Cell. 53 (2014) 726 737, http://dx.doi.org/10.1016/j.molcel.2014.01.013.

[18] B. Pani, B.B. Singh, Lipid rafts/caveolae as microdomains of calcium signaling, Cell Calcium 45 (2009) 625 633, http://dx.doi.org/10.1016/j.ceca.2009.02.009.

[19] A. Fujita, J. Cheng, K. Tauchi-Sato, T. Takenawa, T. Fujimoto, A distinct pool of phosphatidylinositol 4, 5-bisphosphate in caveolae revealed by a nanoscale labeling technique, Proc. Natl. Acad. Sci. U. S. A. 106 (2009) 9256 9261, http://dx.doi.org/ 10.1073/pnas.0900216106.

[20] G. Pedriali, A. Rimessi, L. Sbano, C. Giorgi, M.R. Wieckowski, M. Previati, P. Pinton, Regulation of endoplasmic reticulum-mitochondria $\mathrm{Ca} 2+$ transfer and its importance for anti-cancer therapies, Front. Oncol. 7 (2017) 180, http://dx.doi.org/ 10.3389/fonc. 2017.00180

[21] C. Cárdenas, R.A. Miller, I. Smith, T. Bui, J. Molgó, M. Müller, H. Vais, K.H. Cheung, J. Yang, I. Parker, C.B. Thompson, M.J. Birnbaum, K.R. Hallows, J.K. Foskett, Essential regulation of cell bioenergetics by constitutive InsP3 receptor $\mathrm{Ca} 2$ + transfer to mitochondria, Cell 142 (2010) 270 280, http://dx.doi.org/10. 1016/j.cell.2010.06.007.

[22] C. Lopez-Crisosto, C. Pennanen, C. Vasquez-Trincado, P.E. Morales, R. Bravo-Sagua, A.F.G. Quest, M. Chiong, S. Lavandero, Sarcoplasmic reticulum-mitochondria communication in cardiovascular pathophysiology, Nat. Rev. Cardiol. 14 (2017) 342 360, http://dx.doi.org/10.1038/nrcardio.2017.23.

[23] T. Balla, $\mathrm{Ca}^{2+}$ and lipid signals hold hands at endoplasmic reticulum-plasma membrane contact sites, J. Physiol. (2018), http://dx.doi.org/10.1113/JP274957.

[24] M. Bonora, C. Giorgi, A. Bononi, S. Marchi, S. Patergnani, A. Rimessi, R. Rizzuto, P. Pinton, Subcellular calcium measurements in mammalian cells using jellyfish photoprotein aequorin-based probes, Nat. Protoc. 8 (2013) 2105 2118, http://dx. doi.org/10.1038/nprot.2013.127.

[25] I. Pulli, T. Blom, C. Lof, M. Magnusson, A. Rimessi, P. Pinton, K. Tornquist, A novel chimeric aequorin fused with caveolin-1 reveals a sphingosine kinase 1-regulated $\mathrm{Ca}(2)(+)$ microdomain in the caveolar compartment, Biochim. Biophys. Acta 2015 (1853) 2173 2182, http://dx.doi.org/10.1016/j.bbamcr.2015.04.005.

[26] D. Yan, M.I. Mäyränpää, J. Wong, J. Perttilä, M. Lehto, M. Jauhiainen, P.T. Kovanen, C. Ehnholm, A.J. Brown, V.M. Olkkonen, OSBP-related protein 8 (ORP8) suppresses $A B C A 1$ expression and cholesterol efflux from macrophages, J. Biol. Chem. 283 (2008) 332 340, http://dx.doi.org/10.1074/jbc.M705313200.

[27] M. Charman, T.R. Colbourne, A. Pietrangelo, L. Kreplak, N.D. Ridgway, Oxysterolbinding protein (OSBP)-related protein 4 (ORP4) is essential for cell proliferation and survival, J. Biol. Chem. 289 (2014) 15705 15717, http://dx.doi.org/10.1074/ jbc.M114.571216.

[28] J.-W. Li, Y.-L. Xiao, C.-F. Lai, N. Lou, H.-L. Ma, B.-Y. Zhu, W.-B. Zhong, D.-G. Yan, Oxysterol-binding protein-related protein $4 \mathrm{~L}$ promotes cell proliferation by sustaining intracellular $\mathrm{Ca} 2+$ homeostasis in cervical carcinoma cell lines, Oncotarget 7 (2016) 65849 65861, http://dx.doi.org/10.18632/oncotarget.11671.

[29] L.S. Jouaville, P. Pinton, C. Bastianutto, G.A. Rutter, R. Rizzuto, Regulation of mitochondrial ATP synthesis by calcium: evidence for a long-term metabolic priming, Proc. Natl. Acad. Sci. U. S. A. 96 (1999) 13807 13812, http://dx.doi.org/ 10.1073/PNAS.96.24.13807.

[30] E.J. Griffiths, G.A. Rutter, Mitochondrial calcium as a key regulator of mitochondrial ATP production in mammalian cells, Biochim. Biophys. Acta Bioenergy 2009 (1787) 1324 1333, http://dx.doi.org/10.1016/J.BBABIO.2009.01.019.

[31] W. Zhong, Q. Yi, B. Xu, S. Li, T. Wang, F. Liu, B. Zhu, P.R. Hoffmann, G. Ji, P. Lei, G. Li, J. Li, J. Li, V.M. Olkkonen, D. Yan, ORP4L is essential for T-cell acute lymphoblastic leukemia cell survival, Nat. Commun. 7 (2016) 12702, http://dx.doi. org/10.1038/ncomms12702.

[32] R. Stoica, K.J. De Vos, S. Paillusson, S. Mueller, R.M. Sancho, K.-F. Lau, G. VizcayBarrena, W.-L. Lin, Y.-F. Xu, J. Lewis, D.W. Dickson, L. Petrucelli, J.C. Mitchell, C.E. Shaw, C.C.J. Miller, ER mitochondria associations are regulated by the VAPB PTPIP51 interaction and are disrupted by ALS/FTD-associated TDP-43, Nat. Commun. 5 (2014) 3996, http://dx.doi.org/10.1038/ncomms4996.

[33] F. Maltecca, D. De Stefani, L. Cassina, F. Consolato, M. Wasilewski, L. Scorrano, R. Rizzuto, G. Casari, Respiratory dysfunction by AFG3L2 deficiency causes decreased mitochondrial calcium uptake via organellar network fragmentation, Hum. Mol. Genet. 21 (2012) 3858 3870, http://dx.doi.org/10.1093/hmg/dds214.

[34] R.G. Parton, M.A. Del Pozo, Caveolae as plasma membrane sensors, protectors and organizers, Nat. Rev. Mol. Cell Biol. 14 (2013) 98 112, http://dx.doi.org/10.1038/ nrm3512.

[35] A. Adebiyi, D. Narayanan, J.H. Jaggar, Caveolin-1 assembles type 1 inositol 1,4,5trisphosphate receptors and canonical transient receptor potential 3 channels into a functional signaling complex in arterial smooth muscle cells, J. Biol. Chem. 286 (2011) 4341 4348, http://dx.doi.org/10.1074/jbc.M110.179747.

[36] P.C. Sundivakkam, A.M. Kwiatek, T.T. Sharma, R.D. Minshall, A.B. Malik, C. Tiruppathi, Caveolin-1 scaffold domain interacts with TRPC1 and IP3R3 to regulate $\mathrm{Ca} 2+$ store release-induced $\mathrm{Ca} 2+$ entry in endothelial cells, AJP Cell Physiol. 296 (2008) C403 C413, http://dx.doi.org/10.1152/ajpcell.00470.2008.

[37] O. Béaslas, T. Vihervaara, J. Li, P.-P. Laurila, D. Yan, V.M. Olkkonen, Silencing of OSBP-related protein 8 (ORP8) modifies the macrophage transcriptome, nucleoporin p62 distribution, and migration capacity, Exp. Cell Res. 318 (2012) 1933 1945, http://dx.doi.org/10.1016/j.yexcr.2012.05.026.

[38] A.G. Manford, C.J. Stefan, H.L. Yuan, J.A. MacGurn, S.D. Emr, ER-to-plasma 
membrane tethering proteins regulate cell signaling and ER morphology, Dev. Cell. 23 (2012) 1129 1140, http://dx.doi.org/10.1016/j.devcel.2012.11.004.

[39] J. Maléth, S. Choi, S. Muallem, M. Ahuja, Translocation between PI(4, 5)P2-poor and PI(4, 5)P2-rich microdomains during store depletion determines STIM1 conformation and Orai1 gating, Nat. Commun. 5 (2014) 5843, http://dx.doi.org/10. 1038/ncomms6843.

[40] J.W. Putney, L.M. Broad, F.-J. Braun, J.-P. Lievremont, G.S.J. Bird, Mechanisms of capacitative calcium entry, J. Cell Sci. 114 (2001) 2223 (LP-2229), http://jcs. biologists.org/content/114/12/2223.abstract.

[41] K.P. Lee, J.P. Yuan, J.H. Hong, I. So, P.F. Worley, S. Muallem, An endoplasmic reticulum/plasma membrane junction: STIM1/Orai1/TRPCs, FEBS Lett. 584 (2010) 2022 2027, http://dx.doi.org/10.1016/j.febslet.2009.11.078.

[42] X. Du, A. Zadoorian, I.E. Lukmantara, Y. Qi, A.J. Brown, H. Yang, Oxysterol-binding protein-related protein 5 (ORP5) promotes cell proliferation by activation of mTORC1 signaling, J. Biol. Chem. (2018), http://dx.doi.org/10.1074/jbc.RA117. 001558 (jbc.RA117.001558)

[43] X. Guo, L. Zhang, Y. Fan, D. Zhang, L. Qin, S. Dong, G. Li, Oxysterol-binding protein-related protein 8 inhibits gastric cancer growth through induction of ER stress, inhibition of wnt signaling, and activation of apoptosis, Oncol. Res. Featur. Preclin.
Clin. Cancer Ther. 25 (2017) 799 808, http://dx.doi.org/10.3727/ $096504016 \times 14783691306605$.

[44] W. Zhong, S. Qin, B. Zhu, M. Pu, F. Liu, L. Wang, G. Ye, Q. Yi, D. Yan, Oxysterolbinding protein-related protein 8 (ORP8) increases sensitivity of hepatocellular carcinoma cells to Fas-mediated apoptosis, J. Biol. Chem. 290 (2015) 88768887 http://dx.doi.org/10.1074/jbc.M114.610188.

[45] A.L. Wozniak, X. Wang, E.S. Stieren, S.G. Scarbrough, C.J. Elferink, D. Boehning, Requirement of biphasic calcium release from the endoplasmic reticulum for Fasmediated apoptosis, J. Cell Biol. 175 (2006) 709 714, http://dx.doi.org/10.1083/ jcb. 200608035.

[46] S. Marchi, S. Patergnani, S. Missiroli, G. Morciano, A. Rimessi, M.R. Wieckowski, C. Giorgi, P. Pinton, Mitochondrial and endoplasmic reticulum calcium homeostasis and cell death, Cell Calcium (2017), http://dx.doi.org/10.1016/J.CECA.2017.05. 003 .

[47] M. Kerkhofs, C. Giorgi, S. Marchi, B. Seitaj, J.B. Parys, P. Pinton, G. Bultynck, M. Bittremieux, Alterations in $\mathrm{Ca} 2+$ Signalling via ER-Mitochondria Contact Site Remodelling in Cancer, Springer, Singapore, 2017, pp. 225 254, http://dx.doi.org/ 10.1007/978-981-10-4567-7_17. 